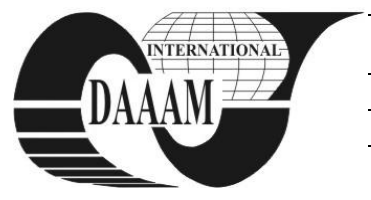

\title{
THE CHEMICAL RESISTANCE OF AN ULTRA-HIGH PERFORMANCE CONCRETE
}

\author{
BUCHMAN, I[osif] \& IGNATON, E[lemer]
}

\begin{abstract}
The paper presents the laboratory researches that have been carried out on special industrial concrete (SIC) for the checking of its chemical resistance. The concrete samples, with a compression strength of about $200 \mathrm{~N} / \mathrm{mm}^{2}$, have been kept for 600 days in a solution of ammonium nitrate with $62.2 \%$ concentration. Although the ammonium nitrate solution has been very concentrated, and the attack period has been very long, the special industrial concrete samples have lost only $10 \%$ of the compression strength

Key words: chemical resistance, ammonium nitrate, attack period, compression strength, silica fume
\end{abstract}

\section{INTRODUCTION}

The objectives most often attacked regarding the ammonium ions are the units of production, transport, storage, handling, and use of the chemical compounds with $\mathrm{NH}_{4}{ }^{+}$; the residual water treatment stations or the buildings which are in the neighbourhood of these units.

The damage may affect the following elements:

- buildings foundations (store-houses, production shops etc.);

- concrete platforms (for handling, loading-unloading);

- supporting pillars;

- the basin walls of residual water treatment stations; concrete sewers (for rain water flow or for residual industrial solutions discharge);

- approaches (roads, bridges);

- dams, etc.

The corrosion brought about by the ammonium salt on concrete may lead to the generation of calcium salts soluble in water and ammonia. These compounds are easily removed causing the increase of concrete porosity, bringing about a series of negative consequences, among which the reduction of mechanical strength and of the resistance to subsequent chemical attacks (Buchman \& Făgădar, 2003).

The paper synthesizes the authors' researches regarding the ammonium nitrate attack $\left(\mathrm{NH}_{4} \mathrm{NO}_{3}\right)$ on special industrial concrete with a compression strength of about $200 \mathrm{~N} / \mathrm{mm}^{2}$ (looked upon as ultra-high performance concrete).

The aim was the reduction of the compression strength following the samples keeping, for 600 days, in an ammonium nitrate solution with $62.2 \%$ concentration (Buchman \& Badea, 2005).

\section{EXPERIMENTAL PROGRAMME. RESULTS}

There have been obtained and tested 3 types of materials:

- special industrial concrete;

- mark concrete for the special industrial concrete (without steel fibres);

- standard mortar for the cement class.

The compositions of these materials and the characteristics of the components are given in the tables 1,2 , and 3 . The cement, the silica, the sand, and the gravel are from Romania, and the sand for the standard mortar from France, the steel fibres from Belgiue, and the superplasticizer are from Germani (Fig. 4).
Concretes preparing has been carried out with a wet mixer with forced mixing. The mixing technology consisted in:

- the cement mixing with silica in the wet mixer tank;

- the introducing of water and superplasticizer and then mixing with reduced speed for 1 minute followed by the mixing with high speed for 1 minute;

- the $0 \ldots 4 \mathrm{~mm}$ sand adding followed by mixing with reduced speed for 1 minute;

- the $4 \ldots 8 \mathrm{~mm}$ gravel adding followed by mixing with high speed for 1 minute;

For the special industrial concrete with steel fibers, there has first been prepared the concrete without steel fibers, according to the above shown technology, and then, the steel fibers have been manually introduced, as follows:

- the addition of $1 / 2$ of the fibers quantity, followed by reduced velocity mixing for 30 seconds;

- the addition of the other $1 / 2$ of the fibers quantity, followed by reduced velocity mixing for 30 seconds.

The standard mortar preparing has followed up the technology provided by the norms in force (EN 196/1).

Out of each composition there have been cast 6 prismatic samples of 40x40x160 mm. Mould compaction has been made

\begin{tabular}{|c|c|c|c|c|c|}
\hline$\% \mathrm{SiO}_{2}$ & $\% \mathrm{Fe}_{2} \mathrm{O}_{3}$ & $\% \mathrm{Al}_{2} \mathrm{O}_{3}$ & $\% \mathrm{CaO}$ & $\% \mathrm{MgO}$ & $\% \mathrm{MnO}$ \\
\hline 91.07 & 1.83 & 4.63 & 0.50 & 0.50 & 1.04 \\
\hline
\end{tabular}

Tab. 1. The silica fume composition

\begin{tabular}{|c|c|c|c|}
\hline \multirow[b]{2}{*}{ Component } & \multicolumn{3}{|c|}{ Material } \\
\hline & $\begin{array}{c}\text { Special } \\
\text { industrial } \\
\text { concrete }\end{array}$ & $\begin{array}{l}\text { Mark concre- } \\
\text { te for the spe- } \\
\text { cial industrial } \\
\text { concrete }\end{array}$ & $\begin{array}{c}\text { Standard } \\
\text { mortar }\end{array}$ \\
\hline $\begin{array}{l}\text { Cement CEM I } \\
42.5 \mathrm{R}, \mathrm{kg} / \mathrm{m}^{3}\end{array}$ & 1053 & 1053 & 502 \\
\hline $\begin{array}{l}\text { Silica fume } \\
\text { (SUF), } \mathrm{kg} / \mathrm{m}^{3}\end{array}$ & 161 & 161 & - \\
\hline $\begin{array}{l}\text { Sand } 0 \ldots 4 \mathrm{~mm}, \\
\mathrm{~kg} / \mathrm{m}^{3}\end{array}$ & 558 & 558 & - \\
\hline $\begin{array}{l}\text { Gravel } 4 \ldots 8 \\
\mathrm{~mm}, \mathrm{~kg} / \mathrm{m}^{3}\end{array}$ & 454 & 454 & - \\
\hline $\begin{array}{l}\text { Sand for the } \\
\text { standard mortar, } \\
\mathrm{kg} / \mathrm{m}^{3}\end{array}$ & - & - & 1506 \\
\hline $\begin{array}{l}\text { Steel fibres, } 1= \\
13 \mathrm{~mm}, \mathrm{~d}=0.16 \\
\mathrm{~mm}, \mathrm{~kg} / \mathrm{m}^{3}\end{array}$ & 230 & - & - \\
\hline $\begin{array}{l}\text { Superplasticizer } \\
\text { FM } 40 \\
\text { (solution), } \\
\mathrm{kg} / \mathrm{m}^{3}\end{array}$ & 57.5 & 57.5 & - \\
\hline Water, $\mathrm{kg} / \mathrm{m}^{3}$ & 195.5 & 195.5 & 251 \\
\hline $\mathrm{W} / \mathrm{C}$ & 0.19 & 0.19 & 0.5 \\
\hline $\mathrm{W} /(\mathrm{C}+\mathrm{SUF})$ & 0.16 & 0.16 & - \\
\hline
\end{tabular}

Tab. 2. The materials composition 


\begin{tabular}{|l|l|}
\hline Characteristic & Technical data \\
\hline Aspect & Liquid \\
\hline Color & Brown \\
\hline Density & $1.05 \pm 0.02 \mathrm{~g} / \mathrm{cm}^{3}\left(\mathrm{la} 20^{\circ} \mathrm{C}\right)$ \\
\hline $\begin{array}{l}\text { The basic active } \\
\text { substance }\end{array}$ & polycarboxilateter \\
\hline Chlorides contents & $\leq 0.1 \%$ \\
\hline
\end{tabular}

Tab. 3. The (FM 40) superplasticizer characteristics

\begin{tabular}{|l|l|}
\hline Characteristic & Technical data \\
\hline Aspect & Circular, smooth, straight section \\
\hline Carbon content & $(0.69 \ldots 0.76) \%$ \\
\hline $\begin{array}{l}\text { Tensile } \\
\text { minimum } \\
\text { strength }\end{array}$ & $2000 \mathrm{~N} / \mathrm{mm} 2$ \\
\hline Diameter & $0.16 \mathrm{~mm}$ \\
\hline Length & $13 \mathrm{~mm}$ \\
\hline Source & Steel dead-drawn wire \\
\hline
\end{tabular}

Tab. 4. The steel fibers characteristics

through vibration. The samples have been kept, for 28 days, in water at the temperature of $20{ }^{\circ} \mathrm{C}$.

Following hardening and drying, there have been used 3 samples out of each composition to establish the apparent density and the compression strength after 28 days. The other samples have been kept in laboratory conditions $\left(20{ }^{\circ} \mathrm{C}\right.$ and about $60 \%$ relative humidity) in a solution of ammonium nitrate $\left(\mathrm{NH}_{4} \mathrm{NO}_{3}\right)$ of $62.2 \%$ concentration, for 600 days, and then there has been defined the compression strength.

The compression test has been made according to the technology used for the defining of cements class.

The apparent density and the compression strength are presented in table 5 (Buchman \& Badea, 2005).

The visual examination of the samples, which have undergone the chemical attack, has not highlighted any sign of their damage. The compression test has led to the results from table 6 (Buchman, 1999).

The results which have been obtained witness a very good behaviour of the special industrial concrete. Although the ammonium nitrate solution was very concentrated and the period of attack was very long, the samples of special industrial concrete have lost only $10 \%$ of the compression strength, while the samples of the other materials have lost $13.4 \%$ (the mark without fibres), and even $74.9 \%$ of the the initial strength (the standard mortar).

\begin{tabular}{|l|c|c|}
\hline \multicolumn{1}{|c|}{ Material } & $\begin{array}{c}\text { Apparent density, } \\
\mathrm{kg} / \mathrm{m}^{3}\end{array}$ & $\begin{array}{c}\text { Compression } \\
\text { strength, } \\
\mathrm{N} / \mathrm{mm}^{2}\end{array}$ \\
\hline $\begin{array}{l}\text { Special industrial } \\
\text { concrete }\end{array}$ & 2575 & 204 \\
\hline $\begin{array}{l}\text { Mark concrete for the } \\
\text { special industrial } \\
\text { concrete (without } \\
\text { fibres) }\end{array}$ & 2315 & 141.7 \\
\hline Standard mortar & 2145 & 41.1 \\
\hline
\end{tabular}

Tab. 5. The apparent density and the compression strength

\begin{tabular}{|l|c|c|}
\hline \multicolumn{1}{|c|}{ Material } & $\begin{array}{c}\text { Compression } \\
\text { strength, } \\
\mathrm{N} / \mathrm{mm}^{2}\end{array}$ & $\begin{array}{c}\text { Strength } \\
\text { reduction, } \\
\%\end{array}$ \\
\hline Special industrial concrete & 183,5 & 10 \\
\hline $\begin{array}{l}\text { Mark concrete for the SIC } \\
\text { (without fibres) }\end{array}$ & 122.7 & 13.4 \\
\hline Standard mortar & 10.3 & 74.9 \\
\hline
\end{tabular}

Tab. 6. Compression strength after 600 days of attack with $\mathrm{NH}_{4} \mathrm{NO}_{3}$

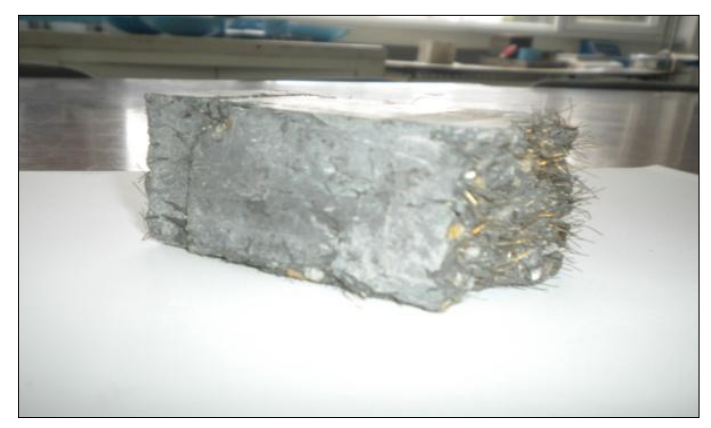

Fig. 1. Mark concrete - after compression test

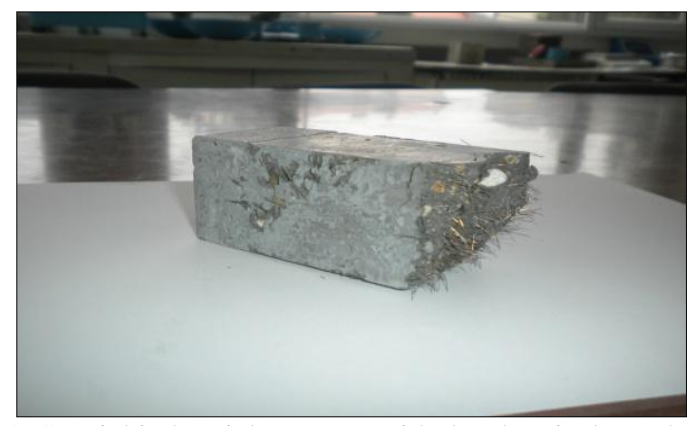

Fig. 2. Special industrial concrete with the chemical attack after compression test

\section{CONCLUSION}

Following the experimental studies and researches that have been made so far, there can be drawn out the conclusions given below:

- The high performance concretes preparing and placement can be carried out by using the same equipment and procedures employed for the usual concrete.

- The chemical strength of the special industrial concrete at the attack of ammonium ions is a high one.

- The studied samples have lost only $10 \%$ of the compression strength, although they have undergone a very severe chemical attack with ammonium nitrate.

- The special industrial concrete is recommended for small dimensions elements, precompressed or not, resistant to aggressive environments, but suppositions may be advanced of its future use at art works, high buldings, chimneys, cooling towers and other.

- The special industrial concrete has been used in France at the restoring of an atomic station instead of reactive powders concretes (RPC 200), the former having the advantage that they do not require thermal treatment (Richard \& Cheyrezy, 1995, Fiche technique, 1998).

\section{REFERENCES}

Buchman, I. (1999). Ultra-high performance concretes, University Horizons Publishing House, ISBNTimişoara

Buchman, I., Badea, C. \& Făgădar, g. (2003). Ultra-high performance concretes, Final report, GRANT, CNCSIS contract, U.P.Timişoara

Buchman, I., Badea, C. (2005). Ultra-high performance concretes, Final report, GRANT, CNCSIS contract, U.P.Timişoara

Richard, P. \& Cheyrezy, M. (1995). Les bétons de poudres réactives, Annales de 1'Institut Technique du Bâtiment et des Travaux Publics, No.532, Paris

*** Betons Un B 150 coule en place, Fiche technique, Maître d'ouvrage: EDF, CNEPE Tours, France, 1998.

*** FM 40 superfluidizer, technical sheet no. kind 10955, Heidelberg Bauchemie, Marke Addiment 